\title{
EXTENDED CONTENTS
}

List of abbreviations

Table of cases

Table of legislation

viii

ix

$\mathrm{xxv}$

Introduction

1. DOING BUSINESS THROUGH A PERMANENT ESTABLISHMENT (PE)

I. OPERATING THROUGH A PERMANENT ESTABLISHMENT

A. The tax PE threshold $\quad 1.03$

B. The tests to determine the existence of a PE $\quad 1.10$

1. The place of business and right of use tests $\quad 1.14$

2. The location and duration tests $\quad 1.19$

3. The business connection test $\quad 1.23$

C. Building sites $\quad 1.28$

$\begin{array}{ll}\text { D. Preparatory/auxiliary activities and anti-fragmentation rule } & 1.35\end{array}$

$\begin{array}{ll}\text { E. The Agency-PE: functional analysis } & 1.48\end{array}$

F. Structures in shipping and air transport $\quad 1.72$

II. FORCE OF ATTRACTION OF THE PE 1.85

A. Which activities are 'attracted' by the PE? $\quad 1.89$

B. Separate treatment of isolated classes of income $\quad 1.105$

III. PROTECTING THE PE OPERATION THROUGH THE NON-DISCRIMINATION CLAUSE 1.110

2. Entitlement to tax treaties

I. SCOPE OF THE TREATIES

A. Personal scope: the basic rule $\quad 2.06$

B. Transparency and hybrid mismatches $\quad 2.10$

1. Transparent entities or arrangements $\quad 2.10$

2. Partnerships 2.17

3. Collective investment vehicles $\quad 2.25$

C. The saving clause $\quad 2.27$

D. Taxes covered by the Treaties $\quad 2.32$

II. RESIDENCE TEST FOR TREATY PURPOSES $\quad 2.39$

A. The notion of 'resident'

B. Dual residents $\quad 2.44$

1. Tie-break rules for individuals 2.48

2. Allocating residence for companies $\quad 2.60$

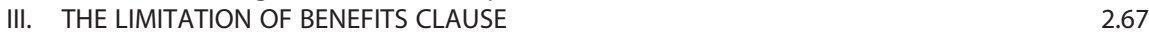

A. Qualified person $\quad 2.73$

B. Active conduct test $\quad 2.81$

C. Derivative benefits and discretionary test $\quad 2.91$

D. Anti-abuse rule for PEs in third countries $\quad 2.98$

$\begin{array}{lr}\text { IV. TREATY ABUSE } & 2.102\end{array}$

A. An integral approach $\quad 2.102$

B. The principal purpose test $\quad 2.109$

C. Improper use of the Convention $\quad 2.116$

1. The evolution of the comprehensive approach 2.116

2. Different approaches to address tax avoidance 2.129

$\begin{array}{ll}\text { 3. Addressing low-taxed treaty income } & 2.135\end{array}$ 
D. Using the 'beneficial owner' concept

3. Operating through corporate vehicles

I. THE FOREIGN-SHAREHOLDER AND THE SUBSIDIARY-PE NON-DISCRIMINATION CLAUSES

II. REMUNERATION ON CORPORATE EQUITY INVESTMENTS

A. Protecting the interests of the SC: the holding requirement 3.11

B. The treaty definition of 'dividends': a moving target 3.26

C. Prohibition of extraterritorial taxation $\quad 3.33$

III. REMUNERATION ON DEBT

$\begin{array}{ll}\text { A. Abusive structures that extract interest } & 3.37\end{array}$

B. 'Interest' and hybrid instruments $\quad 3.46$

IV. REMUNERATION ON INTANGIBLES $\quad 3.52$

A. Allocation rule $\quad 3.52$

B. Definition of 'royalties' $\quad 3.59$

1. Payments that are not royalties, but business profits $\quad 3.64$

2. Payments for know-how $\quad 3.73$

3. Payments for computer software $\quad 3.80$

V. CAPITAL GAINS $\quad 3.95$

A. Capital gains and country of destination: a grey area $\quad 3.95$

B. Gains from the alienation of shares $\quad 3.111$

4. Dispute settlement and enforcement

$\begin{array}{ll}\text { I. THE MUTUAL AGREEMENT PROCEDURE } & 4.02\end{array}$

$\begin{array}{ll}\text { A. The adjudicative MAP } & 4.10\end{array}$

$\begin{array}{ll}\text { 1. Cases and activation } & 4.10\end{array}$

2. MAP procedure and implementation $\quad 4.24$

B. Expanded forms of MAP: normative MAP and arbitration $\quad 4.34$

II. TRANSFER PRICE IN TAX TREATIES $\quad 4.52$

A. Attribution rules for business profits $\quad 4.54$

B. Correlative adjustments of business profits $\quad 4.70$

$\begin{array}{ll}\text { C. Arm's length for associated enterprises } & 4.79\end{array}$

III. TAX TREATIES AND INFORMATION $\quad 4.94$

A. Exchange of information $\quad 4.94$

1. Concept of tax information and scope of exchange $\quad 4.100$

2. Limitations to the exchange of information $\quad 4.114$

3. Violation of domestic laws or administrative practices of the Requested-CS $\quad 4.117$

4. Violation of secrecy rules or public order $\quad 4.123$

5. Information-gathering measures and bank secrecy $\quad 4.129$

$\begin{array}{ll}\text { B. Assistance in the collection of taxes } & 4.137\end{array}$ 